\title{
Histamine H2 Receptor
}

National Cancer Institute

\section{Source}

National Cancer Institute. Histamine H2 Receptor. NCI Thesaurus. Code C41020.

Histamine $\mathrm{H} 2$ receptor ( $359 \mathrm{aa}, \sim 40 \mathrm{kDa}$ ) is encoded by the human $\mathrm{HRH} 2$ gene. This protein is involved in the regulation of gastric acid secretion, gastrointestinal motility, and intestinal secretion. 